\title{
GAMBARAN JUMLAH MONOSIT PADA PETANI TERPAPAR PESTISIDA DI DESA KEBAN AGUNG KABUPATEN KEPAHIANG
}

\section{DESCRIPTION OF THE NUMBER OF MONOCYTES IN FARMERS EXPOSED BY PESTICIDES IN KEBAN AGUNG VILLAGE, KEPAHIANG REGENCY}

\author{
Oleh : \\ Putri Widelia Welkriana ${ }^{1}$ dan Heti Rais Khasanah ${ }^{1}$ \\ (Prodi DIII Teknologi Laboratorium Medis Poltekkes Kemenkes Bengkulu Indonesia) \\ *Email: Putri_widelia2@yahoo.com
}

\begin{abstract}
Background; Monocytes are white blood cells that capable of turning into macrophages in the fight against strange objects that attack the body by getting out of the bloodstream and entering the body's tissues. These cells fight infection by phagocytic germs. Pesticide is a toxic substance that used to remove the plant pest. One of the effects from the explanation of pesticides on health is disarders of the blood profile. Purpose;This study aims to find out the description of the number of monocytes in farmers exposed by pesticides in Keban Agung Village, Kepahiang Regency. Method; This research is a descriptive research with cross sectional research design conducted in the village keban agung research population amounted to 27 respondents. Results; The results of this study can be seen that 20 respondents $(74 \%)$ who have a normal number of monocytes and 7 respondents $(26 \%)$ have an abnormal number of monocytes. Conclusion; It is concluded that most subjects have monocyte counts with normal values.
\end{abstract}

Keywords: Monocytes, Farmers, Pesticides

\section{ABSTRAK}

Latar Belakang; Monosit adalah sel darah putih yang mampu berubah menjadi makrofag dalam memerangi benda-benda asing yang menyerang tubuh dengan keluar dari aliran darah dan masuk kejaringan tubuh.Sel ini melawan infeksi dengan memfagosit kuman. Pestisida adalah suatu zat yang bersifat racun yang berfungsi untuk memberantas organisme pengganggu tanaman. Salah satu dampak dari paparan pestisida terhadap kesehatan yaitu gangguan pada profil darah. Tujuan; Penelitian ini bertujuan untuk mengetahui gambaran jumlah monosit pada petani terpapar pestisida di Desa Keban Agung Kabupaten Kepahiang. Metode; Penelitian ini merupakan penelitian deskriptif dengan desain penelitianCross Sectional yang dilakukan di desa keban agung populasi penelitian berjumlah 27 responden. Hasil; Hasil pada penelitian ini dapat diketahui bahwa 20 responden (74\%) yang memiliki jumlah monosit normal dan 7 responden (26\%) tergolong abnormal. Kesimpulan; Disimpulkan bahwa sebagian besar subyek memiliki jumlah monositdengan nilai yang normal.

\section{Kata Kunci:Monosit, Petani, Pestisida}

\section{PENDAHULUAN}

Petani merupakan kelompok kerja terbesar di Indonesia. Meski terdapat kecenderungan yang semakin menurun, angkatan kerja yang bekerja pada sektor pertanian masih berjumlah sekitar $31,86 \%$ dari jumlah angkatan kerja (Badan Pusat Statistik, 2017). Secara global WHO telah menyurvei bahwa keracunan pestisida pertahunnya dapat mengakibatkan 300.000 kematian dan biasanya terjadi di negara yang berpenghasilan rendah dan menengah. Petani menggunakan berbagai macam pestisida agar tanaman terhindar dari serangan hama yang dapat mengurangi kerugian (Minaka et al., 2016).Petani yang kurang sadar dalam menggunakan APD pada saat melakukan 
penyemprotan menjadi faktor risiko terjadinya keracunan pestisida (Ipmawati et al., 2016). DesaPasirhalang adalah salah satu desa yang berada di wilayah Kecamatan Cisarua, Kabupaten Bandung Barat yang berada di kaki Gunung Burangrang yang merupakan daerah perbukitan dan lembah cocok untuk ditanami berbagai sayuran dan penduduknya sebagian besar bertani. Berdasarkan hasil survei awal pada petani di Desa Pasirhalang, petani masih jarang yang memakai APD, karena kurangnya pengetahuan tentang pentingnya menggunakan APD dan tidak ada penyuluhan kepada petani (Balai Penyuluhan Pertanian, Perikanan dan Kehutanan, 2016), .

Monosit merupakan sel darah putih yang berjumlah 2-8 \% dari keseluruhan darah dengan diameter 14-20 $\mu \mathrm{m}$. Inti biasanya eksentris dan berbentuk seperti tapal kuda dengan kromatin mengelompok. Monosit yang jumlahnya hanya beberapa persen dari keseluruhan darah ini memainkan peran penting dalam sistem kekebalan tubuh, dimana monosit merupakan sel yang mampu berubah menjadi makrofag dalam memerangi bendabenda asing yang meyerang tubuh dengan keluar dari aliran darah dan masuk kejaringan tubuh begitu juga pada sel spermatozoa (Aryoseto, 2013). Sel ini melawan infeksi dengan memfagosit kuman (Nugraha, 2013) dan (Zulkarnaini, 2013).

Menurut data World Health Organization (WHO) 1-5 juta kasus keracunan pestisida terjadi pada pekerja disekitar pertanian, 20.000 orang diantaranya meninggal akibat keracunan pestisida. Jalur masuknya pestisida ke dalam tubuh dapat terjadi melalui tiga jalur pokok yaitu penetrasi melalui kulit (absorbsi kulit), absorbsi melalui paru (inhalasi), dan absorbsi melalui saluran pencernaan (ingesti) (Muhrizal, 2016). Bentuk pemaparan yang paling lazim adalah melalui pernafasan dan kulit. Risiko bagi kesehatan yaitu dalam bentuk keracunan akut dan keracunan kronik yang berjangka panjang. Keracunan akut terjadi karena kecerobohan dan tidak memperhatikan aspek keamanan seperti penggunaan Alat Pelindung Diri (APD). Dampak lain dari paparan pestisida terhadap kesehatan adalah gangguan pada profil
darah(Dimas, 2012). Profil darah merupakan salah satu komponen penting dalam penilaian kesehatan, perkembangan suatu pengobatan, diagnose penyakit seperti anemia, penyakit infeksi, kelainan darah, dan lain sebagainya.(Marianajati dkk, 2012).

Petani di Indonesia masih belum banyak mengetahui mengenai resiko dari penggunaan pestisida. Penggunaan pestisida yang meningkat dan pelatihan yang kurang tepat menyebabkan paparan yang cukup serius. Semakin tinggi daya racun pestisida yang digunakan oleh petani maka semakin tinggi pula risiko petani mengalami gangguan pada profil darah (Zuraida, 2012). Pestisida dapat menimbulkan abnormalitas pada profil darah karena pestisida mengganggu organorgan pembentuk sel darah, pembentukan sel darah dan juga sistem imun(Tani et al. , 2017).

Menurut Maharani, Arifin,Isro'ani (2019) menunjukkan bahwa lebih dari sebagian responden hanya menggunakan sebagian alat pelindung diri yaitu sebanyak 9 orang $(60 \%)$. Menurut opini peneliti, walaupun petani selalu mencuci tangan setelah menyemprot pestisida itu tidak menutup kemungkinan masih tingginya akumulasi paparan. Karena banyak petani yang menggunakan alat pelindung diri yang tidak lengkap. Sedangkan paparan pestisida dapat melalui, oral, kulit, dan inhalasi. Meskipun semua responden selalu mencuci tangan setelah menyemprot besar petani tidak mengenakan APD dengan lengkap. Alat pelindung diri yang lengkap dalam penelitian ini dikatagorikan; petani mengenakan baju lengan panjang, celana panjang, masker, sarung tangan, sepatu boot dan topi. Risiko pestisida masuk kedalam tubuh akan semakin tinggi ketika tidak menggunakan APD yang lengkap dan dengan frekuensi penyemprotan yang tinggi.

Pestisida mampu merusak jaringan sel yang mengandung enzim-enzim penangkal radikal bebas seperti enzim Super Oxide Dimutase (SOD), sehingga pestisida menyebabkan radikal bebas $(\mathrm{OH})$ yang sangat reaktif(Hernayati, 2015). Jika sudah terbentuk dalam tubuh maka akan menyebabkan reaksi berantai yang disebut peroksidasi lipid yang baru sehingga jumlah radikal bebas yang baru 
sehingga jumlah radikal bebas akan selalu bertambah yang akan mengakibatkan stress oksidatif. Stress oksidatif akan memnyebabkan radang, sehingga monosit akan mengatasi radang bersama-sama neutrofil. Jika infeksi tidak dapat segera diatasi di jaringan peradangan, maka jaringan radang akan merangsang sumsum tulang untuk memproduksi monosit dalam jumlah yang sangat banyak dengan kecepatan 20-50 kali lipat diatas normal(Rahmawati dan Martiuana, 2014).

\section{METODE PENELITIAN}

Jenis penelitian ini adalah penelitian deskriptif analitik dengan desain penelitian Cross sectional. Sampel diambil dengan teknik Purposive Sampling dari data petani yang menggunakan pestisida lebih dari 5 tahun di Desa Keban Agung Kabupaten Kepahiang. Penelitian ini peneliti mendeskripsikan dan menganalisis jumlah monosit yang dimiliki oleh petani yang menggunakan pestisida. Purposive Sampling yaitu dengan cara Pengambilan Sampel secara sengaja diambil karena pertimbangan tertentu dan memenuhi segala persyaratan tertentu yang telah ditentukan.

\section{HASIL} monosit.

Berikut tabel interprestasi jumlah

Tabel 1. Interpretasi Jumlah Monosit

\begin{tabular}{llll}
\hline $\begin{array}{l}\text { Interpretasi } \\
\text { jumlah } \\
\text { monosit }\end{array}$ & $\begin{array}{l}\text { Normal } \\
(2 \%)\end{array}$ & $\begin{array}{l}\text { Abnormal } \\
(<2 \%,>8 \%)\end{array}$ & Total \\
\hline Frekuensi & 20 & 7 & 27 \\
\hline $\begin{array}{l}\text { Persentase } \\
(\%)\end{array}$ & 74 & 26 & 100 \\
\hline
\end{tabular}

Dari tabel 1 dapat diketahui bahwa 20 Responden (74\%) tmemiliki jumlah monosit normal dan 7 Responden (26\%) memiliki jumlah monosit yang meningkat.

\section{PEMBAHASAN}

Berdasarkan hasil penelitian yang dilakukan terlihat bahwa rata-rata jumlah jenis leukosit responden masih dalam batas normal bila dibandingkan dengan standarnya terkecuali untuk komponen kadar monosit. Semua responden menunjukkan kadar eosinofil dan basofil yang normal. Hasil penelitian memperlihatkan 20 orang responden (74\%) memiliki jumlah monosit normal dan 7 orang responden $(26 \%)$ memiliki jumlah monosit abnormal. Pada tahun 2015 di kelompok tani wilayah kerja Puskesmas Pal Merah I Kota Jambi telah dilaksanakan pemeriksaan cholinesterase darah pada 320 petani penyemprot dengan hasil 40\% (129) terpapar berat, $52 \%$ (165) terpapar sedang, $7 \%$ (23) terpapar ringan dan $1 \%$ (3) normal. Jenis pestisida yang digunakan pada kelompok tani tersebut adalah golongan organopospat. Hasil penelitian ini sejalan dengan penelitian yang dilakukan oleh Marinajati, Wahyuningsih, dan Suhartono (2012)dan Qomariah dkk (2013). Dalam penelitiannya, Marinajati dkk melakukan penelitian tentang "Hubungan Riwayat Paparan Pestisida Dengan Profil Darah Pada Wanita Usia Subur di Daerah Pertanian Cabai Dan Bawang Merah" Hasil penelitian menunjukkan bahwa adanya hubungan lama paparan pestisida dengan peningkatan jumlah monosit dimana rata-rata jumlah monosit responden adalah $11 \%$. Tidak ada hubungan antara kadar kolinesterase dengan jumlah leukosit dalam darah petani penyemprot. Berdasarkan pemeriksaan kadar kolinesterase dengan menggunakan spectrophotometer yang dilakukan oleh Laboratorium Kesehatan Daerah Kota Semarang, terdapat 2 kategori kelompok untuk jumlah kadar kolinesterase yaitu kelompok dengan kadar kolinesterase normal dan kelompok dengan kadar kolinesterase tidak normal. Kelompok tidak normal terbagi lagi menjadi 3 yaitu keracunan ringan, sedang dan keracunan berat. Berdasar hasil perhitungan didapat hasil kolinesterase pada seluruh responden banyak memiliki kadar kolinesterase yang normal yaitu sebanyak $83,72 \%$ namun masih ada beberapa petani yang masuk dalam kategori keracunan pestisida ringan dan yang masuk kategori tersebut semuanya berjenis kelamin laki-laki. Berdasarkan hasil wawancara pada petani di Desa Keban Agung Kabupaten Kepahiang, 
dapat diketahui bahwa para petani melakukan penyemprotan 2 - 4 hari tergantung dengan luas kebun yang di semprot. Aktivitas tersebut rutin dilakukan dalam 3 - 4 kali dalam satu bulan. Petani yang menjadi responden adalah petani yang telah melakukan aktivitas penyemprotan lebih dari 5 tahun masa kerja Petani juga masih banyak yang tidak menggunakan alat pelindung diri (APD) sehingga petani lebih cepat terpapar pestisida Rustia 2013). Hasil penelitian ini menunjukkan petani yang mengalami kelainan eritrosit memiliki kebiasaan tidak menggunakan alat pelindung diri serta telah terpapar oleh pestisida lebih dari 5 tahun masa kerjaYulianandkk (2017). Ada hubungan antara pemakaian alat pelindung diri dengan kejadian keracunan pestisida pada tenaga kerja yang bekerja di tempat penjualan pestisida dan penelitian yang menyatakan bahwa tenaga kerja yang pemakaian alat pelindung diri tidak memenuhi syarat berisiko keracunan pestisida 9,71 kali dibandingkan dengan tenaga kerja yang pemakaian alat pelindung dirinya memenuhi syarat. Untuk pengetahuan tentang pentingnya menggunakan APD bagi petani penyemprot di Desa Sumberejo sangat baik dimana $81 \%$ dari total responden sudah mengetahui pentingnya memakai APD saat melakukan kegiatan penyemprotan. Untuk petani yang selalu menggunakan APD saat melakukan kegiatan penyemprot sudah $69 \%$ petani selalu memakai APD yang mereka punya. Namun, APD yang mereka pakai jarang dicuci sehingga berpotensi sebagai tempat bakteri. Mereka beralasan bila APD yang mereka pakai hanya itu apabila dicuci maka tidak punya yang lain lagi dan ada juga yang beralasan digunakan berkali-kali terlebih dahulu baru di cuci karena sayang bila dipakai 1 kali langsung dicuci.

Terpaparnya tubuh oleh pestisida berdampak pada komponen yang ada di dalam tubuh manusia, salah satunya sel darahHundekari dkk (2013). Selain itu, Dewi Ayu Susilowati (2017) yang menyatakan bahwa ada hubungan antara kebiasaan merokok dengan kadar serum kolinesterase (Susilowati, Suhartono, Widjanarko, Adi, dan Suratman, 2017). Hasil penelitian Peni Kusumasari (2015) yang menyatakan bahwa ada hubungan antara kebiasaan merokok dengan kadar kolesterase total (Kusumasari, 2015).

Gambaran hitung jenis leukosit pada petani bawang merah yang terpapar pestisida dapat dipengaruhi oleh waktu penyemprotan. Dimana pada Tabel 5.5 Menunjukkan bahwa semua responden melakukan penyemprotan pestisida saat sore hari yaitu sebanyak 15 orang (100\%). Menurut opini peneliti, lebih baik melakukan penyemprotan pada pagi hari karena angin belum terlalu kencang berhembus sehingga dapat meminimalisir paparan melalui inhalasi. Untuk waktu menyemprot semua petani memilih pagi atau sore dengan alasan tidak panas. Waktu yang paling baik untuk melakukan penyemprotan adalah pagi antara jam 07.00-jam 10.00 WIB dan sore hari antara jam 15.00-18.00 WIB. Berdasarkan penelitian di lapangan diketahui bahwa semua petani melakukan penyemprotan lebih dari 2 kali dalam 1 minggu, bahkan ketika musim hujan penyemprotan bisa dilakukan setiap hari karena serangan hama akan lebih banyak (Afriyanto, 2008).

Gambaran hitung jenis leukosit pada petani bawang merah yang terpapar pestisida dapat dipengaruhi oleh hygiene personal, dimana pada menunjukkan bahwa semua responden selalu mencuci tangan setelah menyemprot. Dan dapat juga dipengaruhi oleh kelengkapan penggunaan alat pelindung diri, dimana gambaran hitung jenis leukosit pada petani bawang merah yang terpapar pestisida dapat dipengaruhi oleh frekuensi menyemprot. Dimana pada menunjukkan bahwa lebih dari sebagian responden menyemprot pestisida lebih dari 3 jam sehari yaitu sebanyak 9 orang (60\%). Menurut opini peneliti, semakin lama responden bekerja sebagai penyemprot pestisida akan semakin banyak akumulasi paparan racun dalam tubuh responden yang dapat mempengaruhi profil darah responden. Menurut Afrianto, Pemaparan pestisida pada tubuh manusia dengan frekuensi yang 
sering dan dengan interval waktu yang pendek menyebabkan residu pestisida dalam tubuh menjadi lebih tinggi (Afriyanto, 2018).

Hasil eosinofil tinggi sebanyak 11 responden. Sedangkan pada tabel 5.10 didapatkan hasil neutrofil tinggi sebanyak 11 responden dan pada didapatkan hasil monosit tinggi sebanyak 6 responden. Hasil tersebut sesuai dengan penelitian Dwi Marinajati, Nur Endah W dan Suhartono, (2012) dengan judul "Hubungan Riwayat Paparan Pestisida dengan Profil Darah pada Wanita Usia Subur di Daerah Pertanian Cabai dan Bawang Merah" yang mendapatkan jumlah leukosit masih dalam batas normal $(8,42 \pm 2,16)$, sedangkan jenis leukosit yang meningkat adalah monosit 11,4 $\pm 4,58$. Pengaruh pestisida terhadap parameter hematologi pada petani penyemprot dan diperoleh hasil penurunan yang signifikan pada trombosit dan peningkatan sel darah putih. melakukan studi terhadap 53 responden yang terdiri dari 43 orang penyemprot pestisida dan 10 orang yang tidak memiliki riwayat paparan terhadap pestisida. Hasilnya menunjukkan WBC, limfosit dan monosit secara signifikan lebih tinggi kadarnya pada kelompok terpapar dibanding kelompok kontrol $(p<0,01)$.

Dari hasil wawancara terhadap responden penelitian, diketahui bahwa petani sering merasa gatal pada kulit dan sesak nafas terutama setelah melakukan pekerjaan penyemprotan. Eosinofil merupakan salah satu jenis leukosit yang terlibat dalam reaksi alergi, gatal-gatal, penyakit kulit, saluran nafas dan cerna serta infeksi terutama parasit. Peningkatan eosinophil pada penelitian ini kemungkinan karena pestisida dapat meningkatkan radikal bebas dalam tubuh, memicu stress oksidatif pada sel dan menimbulkan reaksi peradangan yang memicu meningkatnya eosinophil.

Dampak negatif radikal bebas terhadap membrane sel terutama endotel pembuluh darah akan meningkatkan ekspresi Intercellular Adhesion Molecule-1 (ICAM-1) dan molekul adhesi lainnya yang akan menarik beberap jenis leukosit seperti monosit dan eosinophil dalam sisrkulasi darah.
Peningkatan ICAM-1 akan mengundang monosit, leukosit dan bioaktif darah lainnya menuju tempat lesi.

Adanya peningkatan peroksidasi lipid akibat pestisida dilaporkan oleh Singh et al yang melakukan penelitian terhadap 20 orang penyemprot sebagai kasus dan 20 orang sebagai kontrol. Hasil studi menunjukkan malondialdehyde (MDA) secara signifikan lebih tinggi pada kelompok terpapar dibanding kelompok tidak terpapar. Hal ini merupakan indikator adanya peroksidasi lipid yang tinggi akan merangsang meningkatnya sel leukosit. (Ambali SF,dkk., 2010).

$$
\text { Menurut Budiyono }
$$

kelengkapan pemakaian alat pelindung diri dan mengganti pakaian setelah menyemprot dapat menurunkan risiko keracunan pestisida. Hasil penelitian Budiono mendapatkan besar proporsi absorbsi pestisida masuk dalam tubuh jika tidak mengganti pakaian setelah menyemprot bawang merah sebesar $64,72 \%$. Tidak mandi setelah menyemprot dengan proporsi $55,88 \%$ dapat pula meningkatkan keracunan pestisida pada petani penyemprot (Budiyono, 2004).

\section{KESIMPULAN}

Berdasarkan penelitian yang dilakukan, dapat disimpulkan bahwa sebagian besar petani didesa Keban Agung memiliki jumlah monosit normal sebanyak 20 orang (74 $\%$ ), sebagian kecil petani memiliki jumlah monosit abnormal sebanyak 7 orang (26\%).

\section{DAFTAR PUSTAKA}

Afriyanto. (2018). Keracunan Pestisida

pada Petani Penyemprot Cabe di Desa Candi PROSIDING HEFA 3rd 2018 P ISSN 2581 -2270 E ISSN 2614 -6401 196 Karya IImiah untuk Peningkatan Kesehatan Bangsa KecamatanBandungan Kabupaten Semarang. Kesling, Vol. 8 no.1. hal.10-14.

Ambali SF, Abubakar AT, Shittu M, Yaqub LS, KoboPI, Giwa A. Ameliorative. Effect of Zinc on Chlorpyrifos-Induced 
Erythrocyte Fragility inWistar Rats. New York Science Journal.2010;3(5):117-122.

Aryoseto, L. (2013). Hubungan Antara Jumlah Leukosit dengan Morfologi Spermatozoa pada Pasien Infertilitas di Rumah Sakit Dokter Kariadi. Kedokteran, 1-31.

Badan Pusat Statistik, Subdirektorat Publikasi dan Kompilasi Statistik, editor. 2017. Statistik Indonesia 2017. Jakarta: Badan pusat statistik.

Budiyono. (2004). Hubungan Pemaparan Pestisida dengan Gangguan Kesehatan Petani Bawang Merah di Kelurahan Panekan Kecamatan Panekan Kabupaten Magetan, Media Kesehatan Masyarakat Indonesia, vol. 3 no.2. hal. 4348. Departemen Kesehatan RI. Ditjen PPM dan PLP. Direktorat PLP. (1996) .Laporan ProgramPenyehatan Lingkungan Permukiman Tahun 1995/1996. Jakarta.

Dimas, permana ade, Sri, M., \& Osfar, S. (2012). Effects Of Pesticide Residues Contamination In Cabbage (Brassica Oleracea) As A Feed On The Blood Profiles Of New Zealand White Rabbit. Peternakan.

Dinas Pertanian Perkebunan dan Kehutanan. 2016. Program Penyuluhan Pertanian BP3K Kecamatan Cisarua Tahun 2016. Bandung: Pemerintahan Kabupaten Bandung Barat.

Hernayati. (2015). Bahaya Pestisida Terhadap Lingkungan. Bio Unsoed. Retrieved from http://bio.unsoed.ac.id/5471-bahayapestisida-terhadap-lingkungan.

Hundekari, I. A., Suryakar, A. N., \& Rathi, D. B. (2013). Acute organo-phosphorus pesticide poisoning in North Karnataka, India: Oxidative damage, haemoglobin level and total leukocyte. African Health Sciences, 13(1), 129-136. https://doi.org/10.4314/ahs.v14i3.42.

Kusumasari, P. (2015). Hubungan Antara Merokok dengan Kadar Kolesterol pada
Pegawai pabrik Gula Tasikmadu Karanganyar. Universitas Muhamadiyah Surakarta. Retrieved from http://eprints.ums.ac.id/39409/1/11. naskah publikasi.pdf

Maharani, Arifin,Isro'ani. (2019). Gambaran Hitung Jenis Leukosit Pada Petani Bawang Merah Yang Terpapar Pestisida. http://repo.stikesicme-jbg.ac.id/2709/

Marinajati, D., Wahyuningsih, N. E., \& Suhartono. (2012). Hubungan Riwayat Paparan Pestisida Dengan Profil Darah Pada Wanita Usia Subur di Daerah Pertanian Cabai Dan Bawang Merah. Jurnal Kesehatan Lingkungan Indonesia, 11(1), 61-67. Retrieved from http://www.ejournal.undip.ac.id/index.php/ jkli/article/view/4142

Minaka IADA, Sawitri AAS, Wirawan DN. 2016. Hubungan Penggunaan Pestisida dan Alat Pelindung Diri dengan Keluhan Kesehatan pada Petani Hortikultura di Bulengleng, Bali. Public Health and Preventive Medicine Archive, 4(1): 94103.

Muhrizal, S. (2016). Pestisida Pertanian Dan Kehutanan Tahun 2016.

Nugraha, P. P. P., Polii, H., Wungouw, H. I. S., Fisiologi, B., Kedokteran, F., Sam, U., \& Manado, R. (2013). Kelurahan Rurukan Kecamatan Tomohon Timur. Prosiding Seminar Nasional 2010, 1-5.

Qomariah, A., Setiani, O., \& Dangiran, H. L. (2013). Hubungan Pajanan Pestisida Organofosfat terhadap Jumlah Leukosit dalam Darah Petani Penyemprot di Desa Sumberejo Kecamatan Ngablak Ana. Jurnal Kesehatan Masyarakat (EJournal), 1(4), 996-1003.

Rahmawati, Y. D., \& Martiana, T. (2014). Pengaruh faktor karakteristik petani dan metode penyemprotan terhadap kadar kolinesterase. The Indonesian Journal of Occupational Safety, Health, and Environment, 1(1), 85-94. 
Rustia, H. N. (2013). Pengaruh Pajanan Pestisida. Universitas Indonesia.

Susilowati, D. A., Suhartono, S., Widjanarko, B., Adi, M. S., \& Suratman, S. (2017). Perilaku Petani Penyemprot Yang Berhubungan Dengan Kadar Serum Cholinesterase. Media Kesehatan Masyarakat Indonesia. https://doi.org/10.30597/mkmi.v13i4.3 152.

Tani et al. (2017). Ajeng_Indraswari_ACHE. Jurnal Kesehatan, 6-18.

Yuliana, P., Desto Arisandi, \& Puri, retnosetiawati dwi. (2017). Persentase Kejadian Anemia Pada Petani Terpapar Pestisida Di. UAD, Yogyakarta,
(February), 452-457. Retrieved from http://lpp.uad.ac.id/wp-

content/uploads/2017/05/59.-yulianaprasetya-452-457.pdf.

Zulkarnaini. (2013). Proses Fagositosis. Fakultas Kedokteran Banda Aceh.

Zuraida. (2012). Faktor Yang Berhubungan Dengan Tingkat Keracunan Pestisida Pada Petani Di Desa Srimahi Tambun Utara Bekasi Tahun 2012. Universitas Indonesia, 1-77. 